\title{
Evidence that Prohexadione-Calcium Induces Structural Resistance to Fire Blight Infection
}

\author{
Molly J. McGrath, Jessica M. Koczan, Megan M. Kennelly, and George W. Sundin
}

First, second, third, and fourth authors: Department of Plant Pathology, Michigan State University, East Lansing 48824; and third author: Department of Plant Pathology, Kansas State University, Manhattan 66506. Accepted for publication 2 February 2009.

\section{ABSTRACT}

McGrath, M. J., Koczan, J. M., Kennelly, M. M., and Sundin, G. W. 2009. Evidence that prohexadione-calcium induces structural resistance to fire blight infection. Phytopathology 99:591-596.

Mechanisms of fire blight control by the shoot-growth regulator prohexadione-calcium (ProCa) were investigated by comparing disease development in ProCa-treated potted apple trees (cv. Gala) to paclobutrazol (another shoot-growth regulator)-treated and nontreated trees and in ProCa-treated cv. McIntosh trees in the field. Twenty-eight days after inoculation with Erwinia amylovora Ea110, disease incidence on ProCaand paclobutrazol-treated shoots was significantly reduced compared with that on nontreated shoots. Disease severity (percent shoot length infected) was also significantly lower on both ProCa- and paclobutrazol-treated shoots than on nontreated shoots. However, bacterial populations within inoculated shoots were high and bacterial growth occurred in all treatments. In addition, the mean cell wall width of the cortical parenchyma midvein tissue of the first and second youngest unfolded leaves of ProCaand paclobutrazol-treated shoots was significantly wider both 0.5 and $2 \mathrm{~cm}$ from the leaf tips compared with the cell walls of the nontreated tissue. Taken together, these results suggest that reduction of fire blight symptoms by ProCa and paclobutrazol is not the result of reduced populations of E. amylovora in shoots. Moreover, because paclobutrazol also reduced disease severity and incidence, changes in flavonoid metabolism induced by ProCa but not paclobutrazol does not appear to be responsible for disease control as suggested in recent literature. Finally, although this study did not directly link disease control to the observed cell wall changes, the possibility that an increase in cell wall width impedes the spread of E. amylovora should be investigated in more depth.
Fire blight, caused by the bacterium Erwinia amylovora, is a destructive and economically important disease of apple and pear. There are several distinct phases of the disease, including blossom blight, shoot blight, and rootstock blight (21). The diversity of susceptible host tissues, combined with the limited number of management tools available to control the disease, has made it difficult to stop or slow the progress of fire blight epidemics. Streptomycin has been the primary material for the effective control of blossom blight but resistance to streptomycin occurs widely in the western United States and has developed in some regions of Michigan $(2,14,16,18)$. The blossom blight phase of fire blight is initiated in the spring following the epiphytic colonization of blossom stigmas (10,32). Surface-associated populations of E. amylovora on blossoms remain the only effective target for control attempts utilizing bactericides (25). Alternative blossom blight control materials such as the antibiotic oxytetracycline or biological control agents, including Serenade MAX, BlightBan A506, and Bloomtime E325, are typically less effective than streptomycin $(18,31)$.

After bloom, blossom blight infections and active limb cankers provide the inoculum for shoot blight infections, which are most severe on actively growing shoots. Succulent new growth is vulnerable to damage during storms, especially those with winddriven rain (17). Wounding is an important predisposition factor for fire blight infection $(1,4)$, and trauma events such as wind or hail storms not only wound trees but also introduce $E$. amylovora cells to internal tissues. These internalized populations are not affected by streptomycin unless applications are made optimally within 4 to $6 \mathrm{~h}$ of the trauma event $(22,33)$. Antibiotics are not

Corresponding author:: G. W. Sundin; E-mail address: sundin@msu.edu

doi:10.1094/PHYTO-99-5-0591

(C) 2009 The American Phytopathological Society recommended for shoot blight control due to antibiotic resistance concerns (11). Thus, the lack of tools available for shoot blight management is a critical limiting factor in overall fire blight management, and alternate tools for shoot blight management would be beneficial for growers.

A number of chemicals have been developed to regulate growth in apple (24), including prohexadione-calcium (ProCa) (6). ProCa is a plant growth regulator that acts as a structural mimic of 2-oxoglutaric acid and inhibits late steps of gibberellin biosynthesis, resulting in reduced shoot growth $(6,26)$. In addition to growth control, ProCa has been observed to reduce the incidence of shoot blight in apple $(19-21,34)$ and pear (3). ProCa reduced both disease incidence and severity on inoculated shoots and secondary spread from the inoculated shoots to noninoculated shoots (7).

The mechanism by which ProCa reduces fire blight infection is unknown, although there is a correlation between disease control and growth control (21). However, reductions in fire blight have been observed without any concomitant reduction in shoot growth (7). There are many potential mechanisms of control; however, one possible mechanism that has been proposed is that ProCa induces resistance in the host by triggering alternate biosynthetic pathways leading to the production of flavonoid antimicrobial compounds such as luteoflavin and luteoforol $(8,9,29)$. Luteoforol is a transiently occurring flavonoid that is not normally produced in rosaceous species but is apparently produced in apple treated with ProCa $(8,27,29)$. This compound has been shown to inhibit E. amylovora in vitro (29). Another growth regulator, paclobutrazol, blocks earlier steps (compared with ProCa) in the gibberellin biosynthesis pathway, and is not known to induce the production of luteoflavin or luteoforol (8). As a result, if the antimicrobial activity of luteoforol is responsible for the control of shoot blight, reductions in disease incidence and severity would not be expected with the application of paclobutrazol. 
Other possible mechanisms for ProCa-mediated fire blight control center on effects related to reductions in tree vigor. For example, the sorbitol content of young, actively growing apple tissue is significantly reduced compared with nongrowing tissue (13), and lower sorbitol content in shoots is associated with increased fire blight susceptibility (30). Another possibility is through the occurrence of anatomical changes in plant tissue associated with reduced growth. Young, expanding shoot tissue is characterized by the formation of protoxylem; as tissue expansion stops, protoxylem is converted to metaxylem elements which contain uniformly thickened cell walls that are more lignified (5). Paclobutrazol has been shown to cause structural changes in the leaf tissue of rape (36), maize (28), and Chinese potato (12). Changes in the cellular anatomy of apple shoot tissue could potentially impede the movement of E. amylovora through shoot tissue.

Our overall goal in this study was to investigate the potential mechanism of shoot blight control by ProCa. Our first objective was to compare symptom development and E. amylovora population growth in ProCa-, paclobutrazol-, and nontreated trees. Our second objective was to use scanning electron microscopy to compare the width of cell walls from midvein cortical tissue from ProCa-, paclobutrazol-, and nontreated leaves.

\section{MATERIALS AND METHODS}

Bacterial strain and growth conditions. The virulent, rifampicin-resistant strain E. amylovora Ea110 (15) was used for all experiments. The bacterium was cultured on Luria-Bertani agar medium amended with rifampicin at $100 \mu \mathrm{g} / \mathrm{ml}(\mathrm{LB}+\mathrm{rif})$ at $28^{\circ} \mathrm{C}$ unless otherwise noted. For inoculations and bacterial enumeration, cells were diluted in $0.5 \times$ phosphate-buffered saline (PBS).

Plant material. Experiments with potted apple trees were conducted using 2-year-old apple cv. Gala on M-9 rootstock (Hilltop Fruit Trees, Hartford, MI). These trees were potted in 11.3liter pots in a 3:1 mixture of Bacto Hi-porosity soil mix (Michigan Peat Company) to field soil. Trees were placed in a Michigan State University (East Lansing, MI) greenhouse and watered and pruned (experiments conducted $\approx 6$ weeks after pruning, on actively growing tissue) as necessary until experiments were conducted. Trees selected to study disease development were randomized and placed outside the greenhouse. Trees used for microscopy studies were placed in a growth chamber $(12 \mathrm{~h}$ of light and $12 \mathrm{~h}$ of dark conditions maintained at $25^{\circ} \mathrm{C}$ ). Field experiments were conducted using 26-year-old apple cv. McIntosh trees located in a Michigan State University orchard.

Application of shoot-growth regulators. ProCa (formulated as Apogee, $27.5 \%$ a.i. prohexadione calcium, BASF) and paclobutrazol (Cambistat Rainbow Treecare Scientific Advancements, $22.3 \%$ a.i. paclobutrazol) were applied to eight potted apple trees on 7 July 2006. The ProCa treatment was applied at $0.9 \mathrm{~g}$ of Apogee with $1.2 \mathrm{ml}$ of Regulaid (Kalo Inc.) and $0.9 \mathrm{~g}$ of ammonium sulfate per $946.1 \mathrm{ml}$ of water $(0.26 \mathrm{mg}$ a.i $/ \mathrm{ml})$. Leaves and shoots were sprayed to run-off with this mixture. The paclobutrazol treatment was applied to the soil of each potted tree (basal drench) at $12.5 \mathrm{ml}$ of Cambistat with $0.18 \mathrm{ml}$ of Regulaid and $0.14 \mathrm{~g}$ of ammonium sulfate per $137.5 \mathrm{ml}$ of water $(21.7 \mathrm{mg}$ a.i./ml). Eight additional trees were left untreated. This was repeated on both 7 July and 7 September 2007 with ProCa and paclobutrazol applied to 10 and 8 trees/treatment, respectively. On 6 November 2007, ProCa and paclobutrazol were applied to four potted apple trees each, with three trees left untreated. These trees were used to generate tissue for microscopy.

ProCa treatments for field experiments were assigned in a completely randomized design, and ProCa was applied to trees to run-off using a handgun sprayer. The high-concentration ProCa treatment was applied to six trees with Apogee at $250 \mathrm{mg} / \mathrm{liter}$ on 23 May 2005. The low-concentration treatment was applied to six trees as a split application, with Apogee at $125 \mathrm{mg} / \mathrm{liter}$ applied on
23 May and a second application on 2 June 2005. Regulaid (1.25 ml/liter) and ammonium sulfate $(0.9 \mathrm{~g} /$ liter $)$ were mixed with Apogee prior to application. Six trees were left untreated.

Bacterial inoculation. Potted apple tree shoots were inoculated with E. amylovora Ea110 or $0.5 \times$ PBS (control) by cutting $1 \mathrm{~cm}$ from the tips of the two newest unfolded leaves on each shoot using a scissors dipped in the bacterial suspension $\left(10^{8} \mathrm{CFU} / \mathrm{ml}\right)$ before each cut (scissor-cut inoculation method). Shoots were inoculated on 17 July 2006, 23 July 2007, and 21 September 2007. Following inoculation, plastic bags were placed over shoots and removed the following day.

On 17 June 2005, six randomly selected shoots from each field tree were inoculated with Ea110 $\left(3 \times 10^{5} \mathrm{CFU} / \mathrm{ml}\right)$ and six additional shoots/tree were inoculated with a higher concentration of Ea110 $\left(3 \times 10^{5} \mathrm{CFU} / \mathrm{ml}\right)$. All shoots were inoculated by the scissor-cut inoculation method.

Disease evaluation and recovery of bacteria from sampled leaves. Shoot length, disease incidence (presence or absence of a shoot lesion), severity (length of lesion/current season's growth $\times$ 100 ), and conditional severity (assessed by determining severity of diseased shoots only) were assessed over the course of each potted tree experiment.

CFU were determined by destructively sampling 5 randomly chosen shoots/treatment in the first potted tree experiment, 10 shoots/treatment in the final potted tree experiments, and 2 shoots/treatment in the field tree experiments. For each shoot, the inoculated leaf, its petiole, and $2 \mathrm{~cm}$ of shoot basal to the petiole were homogenized with a Polytron PT 10-35 blender (Brinkmann Instruments, Inc.) in $10 \mathrm{ml}$ of chilled $0.5 \times \mathrm{PBS}$, and 10 -fold serial dilutions were plated on LB+rif+cycloheximide. After $72 \mathrm{~h}$, bacterial populations in inoculated shoots were determined using dilution plating.

Determination of cell wall widths in midvein cortical tissue. On 13, 19, and 27 November 2007, five shoots per treatment were randomly selected and the first, second, and seventh youngest unfolded leaves of each shoot were removed. Leaf sections ( 1 by $1 \mathrm{~cm}$, bisected by the midvein) 0.5 and $2 \mathrm{~cm}$ from each leaf tip were removed and fixed in paraformaldehyde/glutaraldehyde, $2.5 \%$ each in $0.1 \mathrm{M}$ sodium cacodylate buffer (Electron Microscopy Sciences, Hatfield, PA) overnight. Tissue was then dehydrated successively in 25, 50,75, and $90 \%$ ethanol for $30 \mathrm{~min}$ each, and $100 \%$ ethanol three times for $15 \mathrm{~min}$. Samples were subsequently dried with a critical point drier (Balzers CPD, Lichtenstein). One $0.5-\mathrm{mm}$ cross-section of the midvein was removed from the center of each block of tissue and mounted on aluminum mounting stubs (Electron Microscopy Sciences, Hatfield, PA), which were coated with gold using a gold sputter coater (EMSCOPE SC500 Sputter coater, Ashford, Kent, Great Britain). Images were captured using a scanning electron microscope (JEOL 6400V; Japan Electron Optics Laboratories) with a LaB6 emitter (Noran EDS) using analySIS software (Soft Imaging System, $\mathrm{GmbH}$ ). Fifty random cell-wall measurements per section of the cortical parenchyma were made using analySIS software.

Statistical analysis. In order to conduct statistical analyses, all data sets were assessed for normality and equality of variance. $E$. amylovora population data were $\log (\mathrm{x}+1)$ transformed prior to analysis. Differences among treatments in populations (CFU/ shoot) from field experiments were assessed using a one-way analysis of variance (ANOVA) followed by Tukey's multiple comparison test (with $P \leq 0.05$ ). In the potted tree experiments, differences among treatments in CFU/shoot, severity, and conditional severity were assessed via the Kruskal-Wallis (nonparametric) ANOVA test followed by the post-hoc Tukey's multiple comparison test. Disease incidence was compared among treatments using Fisher's exact test. Differences in cell wall width among treatments were assessed via the Kruskal-Wallis ANOVA test followed by the post-hoc Games-Howell multiple comparison test. The Mann-Whitney rank sum test was used to compare shoot 
length at the beginning and conclusion of all trials for each treatment. All statistical analyses were conducted with SYSTAT (v.12.02.00; SYSTAT Software, Inc., San Jose, CA).

\section{RESULTS}

Effect of ProCa on disease development and bacterial populations in potted apple trees. Potted apple trees were used to compare the effects of the two shoot-growth regulators on disease development. The size of these trees allowed for full coverage of ProCa, which was applied by spray to trees, and for even application of paclobutrazol, which was applied via basal drench to pots containing each tree. In addition, the size of these trees allowed for shoots to be inoculated uniformly and for
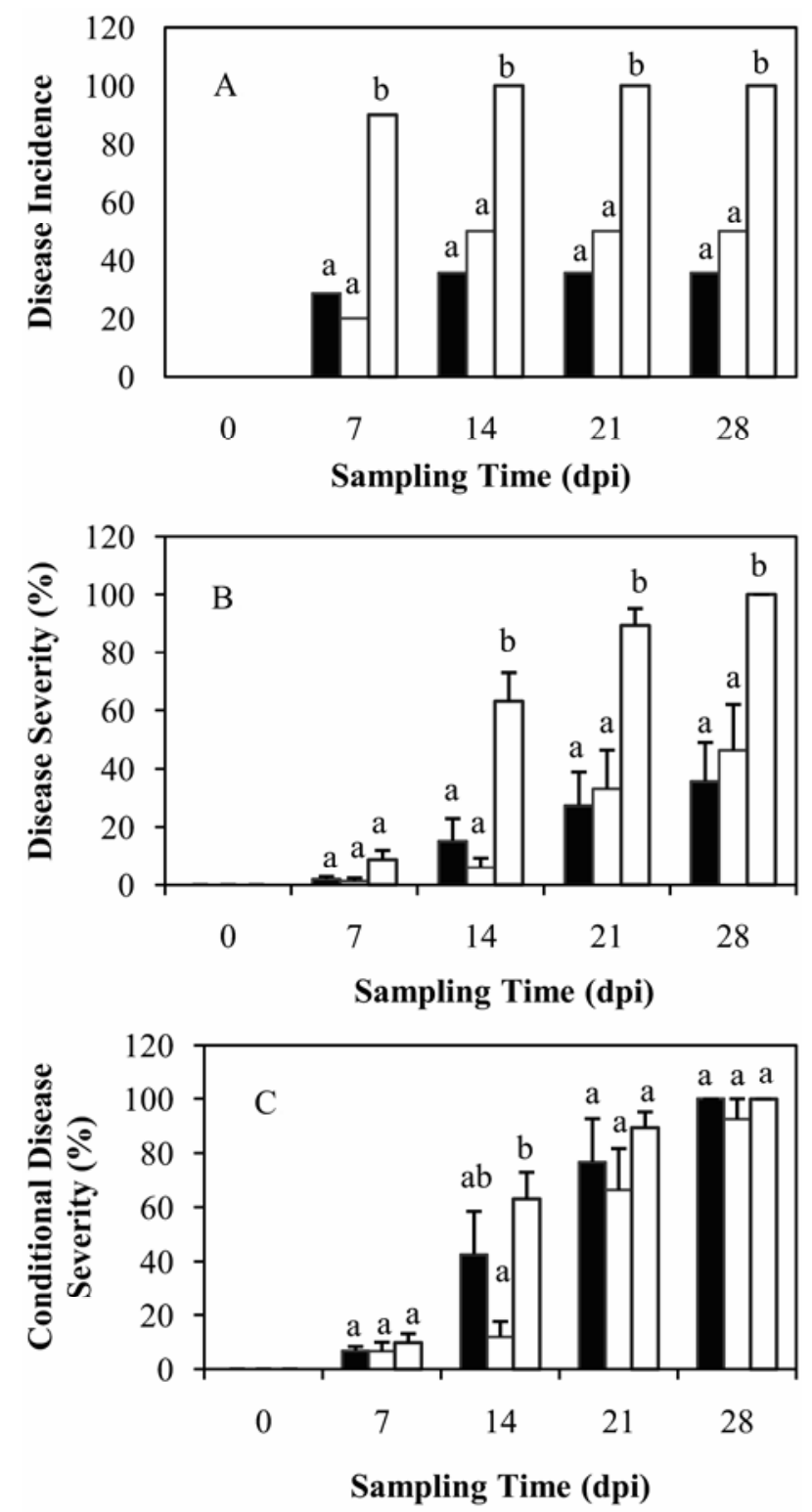

Fig. 1. A, Disease incidence; B, mean disease severity; and $\mathbf{C}$, mean conditional severity on nontreated, (diagonal bars), prohexadione-calcium (ProCa)-treated (black bars), or paclobutrazol-treated (white bars) potted 'Gala' apple trees. Incidence was determined by the presence of a lesion on individual shoots. Severity was ascertained by taking the length of lesion per current season's growth $\times 100$, and conditional severity was determined by taking the length of lesion per current season's growth $\times 100$ on diseased shoots only. Different letters indicate statistical differences $(P \leq 0.05)$. Error bars (B and $\mathbf{C}$ ) display one standard error of the mean. All shoots were inoculated with the virulent strain Erwinia amylovora Ea110 using the scissorcut method. accurate assessment of incidence and severity over time. Results from the three potted tree trials were consistent; therefore, only the results from the final trial are presented. Mean shoot length increased significantly only in nontreated shoots $(4.4 \pm 0.7 \mathrm{~cm}$ at 0 days postinoculation to $10.4 \pm 2.4 \mathrm{~cm}$ at 28 days postinoculation). Mean shoot lengths at 28 days postinoculation in ProCatreated $(3.7 \pm 1.1$ to $5.1 \pm 1.4 \mathrm{~cm})$ and paclobutrazol-treated trees $(5.1 \pm 1.4$ to $7.3 \pm 1.9 \mathrm{~cm})$ were not significantly different $(P \leq$ $0.05)$ from 0 days postinoculation.

Disease incidence at 28 days postinoculation was significantly reduced on both ProCa- and paclobutrazol-treated shoots compared with nontreated shoots (Fig. 1A). There were no significant differences in disease incidence between the paclobutrazol-treated shoots and the ProCa-treated shoots. Disease severity at 14, 21, and 28 days postinoculation was lower on both ProCa- and paclobutrazol-treated shoots compared with nontreated shoots (Fig. 1B). When conditional severity was assessed, there were no significant differences among treatments at 7, 21, and 28 days postinoculation (Fig. 1C). Mean E. amylovora populations increased after inoculation in shoots of all treatments (Fig. 2) with no significant differences at 0 or 28 days postinoculation. E. amylovora cells were distributed throughout ProCa-, paclobutrazol-, and nontreated shoots as detected by sampling and plating excised tissue (data not shown).

Effect of ProCa on bacterial populations in apple shoots in the field. Shoot-growth regulators are commonly applied to mature trees; therefore, bacterial populations were also assessed on field trees to determine whether results were comparable with potted apple trees. Similar results were obtained when the mature trees treated once with Apogee at $250 \mathrm{mg} / \mathrm{liter}$ and twice with Apogee at $125 \mathrm{mg} /$ liter were compared with nontreated trees inoculated with E. amylovora at $3 \times 10^{5} \mathrm{CFU} / \mathrm{ml}$ or $3 \times 10^{7}$ $\mathrm{CFU} / \mathrm{ml}$ (Fig. 3A and B) in that, by the third day after inoculation, growth of E. amylovora was observed in all treatments and, by the conclusion of the experiment, populations of E. amylovora were extremely high in all treatments. In shoots inoculated with $3 \times 10^{7} \mathrm{CFU} / \mathrm{ml}$, there were significant differences in subsequent population size only on day 7 (Fig. 3A). On day 7 , the nontreated control shoots had significantly higher populations than shoots treated with high doses of ProCa (Fig. 3A). In shoots inoculated with $3 \times 10^{5} \mathrm{CFU} / \mathrm{ml}$, the shoots treated with Apogee at 250 $\mathrm{mg} /$ liter supported slightly lower populations than the untreated

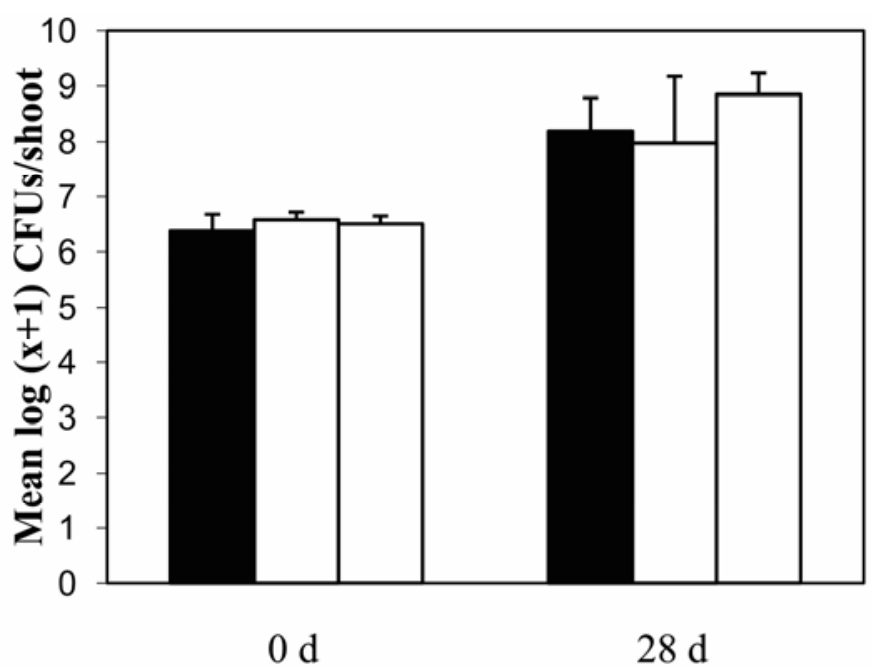

Fig. 2. Mean $\log (x+1) \mathrm{CFU} /$ shoot on nontreated (diagonal bars), prohexadione-calcium (ProCa)-treated (black bars), or paclobutrazol-treated (white bars) potted 'Gala' apple trees at 0 days (initial inoculation), and 28 days postinoculation with the virulent strain Erwinia amylovora Ea110 using the scissor-cut method. No significant differences $(P \leq 0.05)$ among treatments at 0 or 28 days postinoculation were found. Error bars display one standard error of the mean. 
shoots (Fig. 3B), and nontreated control shoots had significantly higher populations than shoots treated with Apogee at $250 \mathrm{mg} / \mathrm{liter}$ at two sampling dates.

Determination of cell wall width in midvein cortical tissue. Microscopy was used to assess whether anatomical changes occurred after the application of shoot-growth regulators. At 7, 13 , and 21 days after treatment, the mean midvein cell wall width (cortical parenchyma tissue) of the first and second unfolded leaves of ProCa- and paclobutrazol-treated shoots was significantly wider both 0.5 and $2 \mathrm{~cm}$ from the leaf tips compared with the cell walls of the nontreated tissue (Fig. 4A to C; Table 1). However, the thickened walls were not uniform across the tissue viewed. The cell wall widths of the seventh leaf at 7 days after application were not significantly different among treatments. At 13 days after treatment, the cell walls (seventh unfolded leaves) of the ProCa- and paclobutrazol-treated shoots were significantly thicker both 0.5 and $2 \mathrm{~cm}$ from the leaf tips. At 21 days after treatment, there were no differences among treatments $0.5 \mathrm{~cm}$ from the leaf tip but, at $2 \mathrm{~cm}$, the cells walls of the ProCa- and paclobutrazol-treated tissue were thicker than the nontreated cell

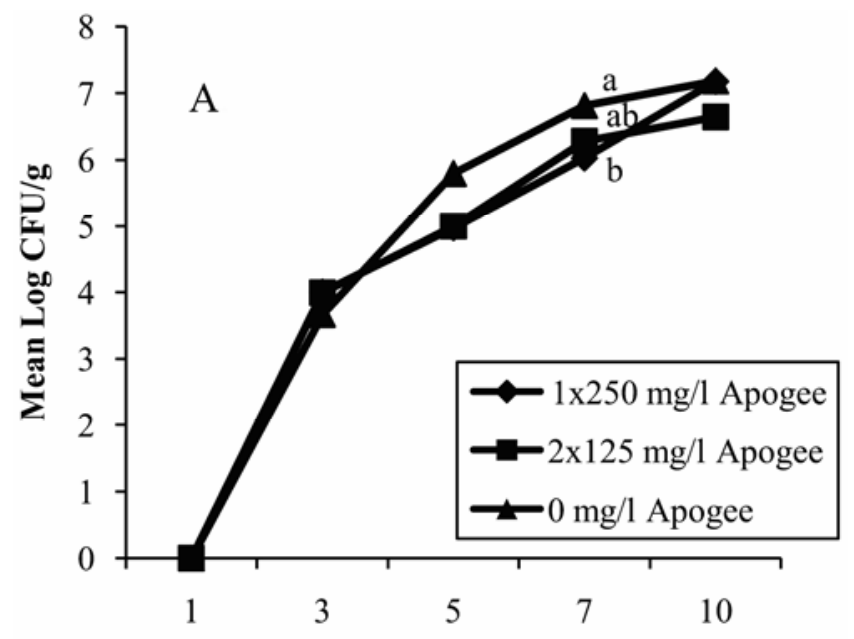

Sampling Time (dpi)

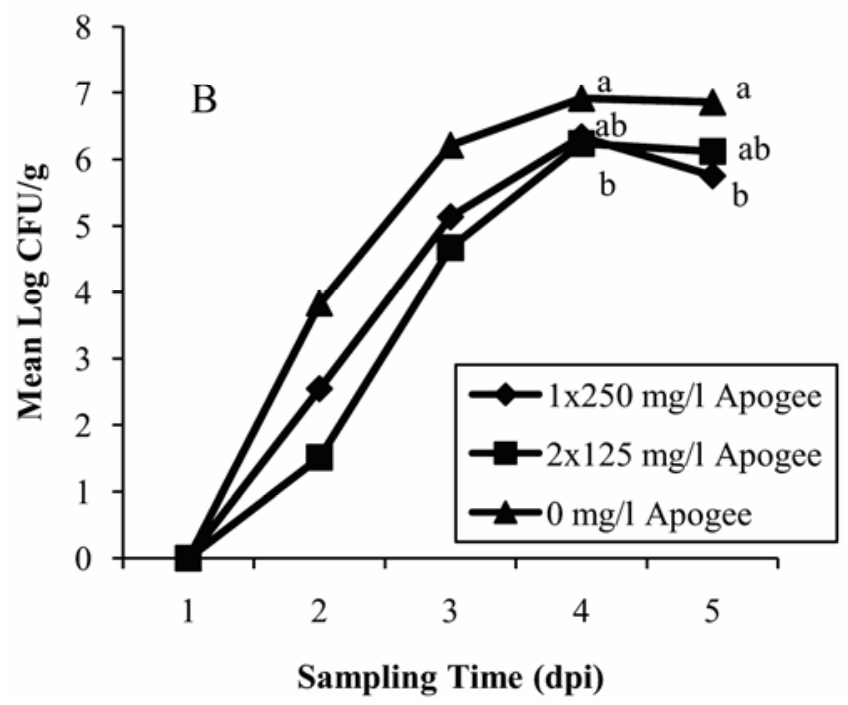

Fig. 3. Mean $\log \mathrm{CFU} / \mathrm{g}$ in shoots of $\mathrm{cv}$. McIntosh treated with one application of prohexadione-calcium (ProCa) (Apogee at $250 \mathrm{mg} / \mathrm{liter}$ ), two applications of ProCa (Apogee at $125 \mathrm{mg} /$ liter), or shoots left untreated after inoculation with the virulent strain Erwinia amylovora Ea110. Shoots were inoculated with either $\mathbf{A}, 3 \times 10^{7} \mathrm{CFU} / \mathrm{ml}$ or $\mathbf{B}, 3 \times 10^{5} \mathrm{CFU} / \mathrm{ml}$ using the scissor-cut method. Different letters indicate differences $(P \leq 0.05)$ among treatments. Where letters are not present, there were no differences $(P \leq 0.05)$.

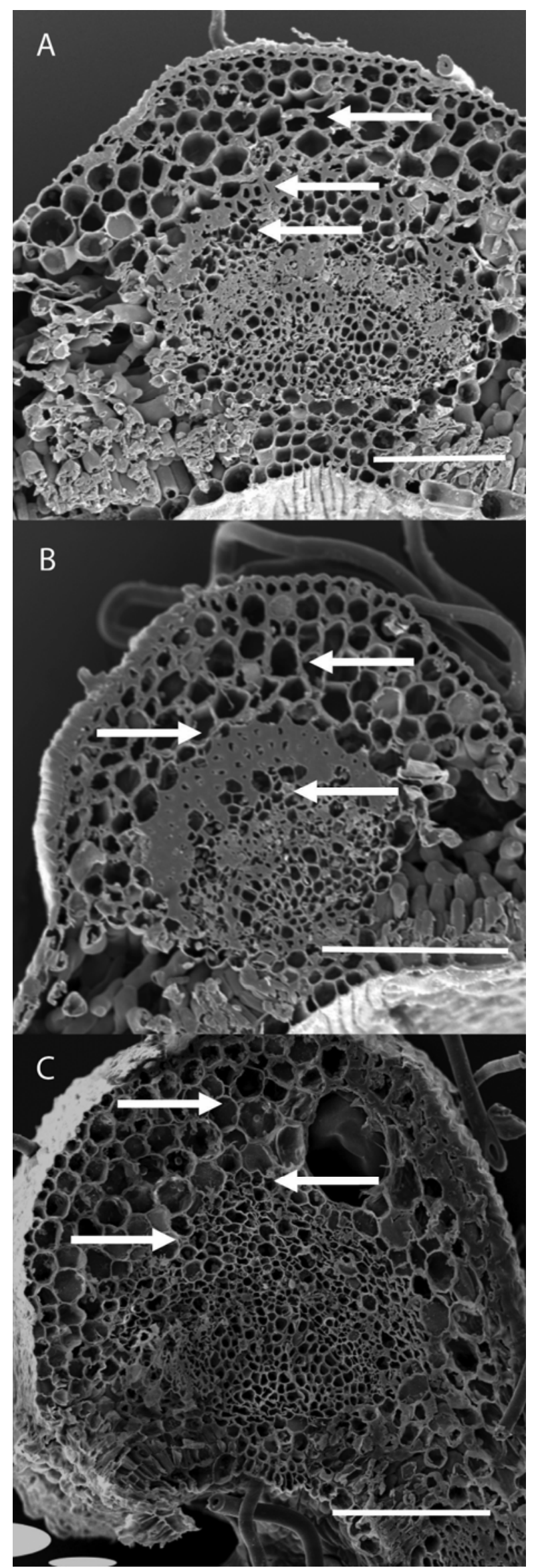

Fig. 4. Apple midvein tissue $2 \mathrm{~cm}$ from the leaf tip of the second-youngest unfolded leaves, 13 days after treatment with $\mathbf{A}$, prohexadione-calcium; $\mathbf{B}$, paclobutrazol; or C, trees left untreated. Scale bars (in white) are $100 \mu \mathrm{m}$ in length. Arrows (A to C) indicate general regions where cell walls were measured. 
walls. Finally, the cell walls of the seventh leaves were compared with the first and second unfolded leaves of the nontreated tissue over time. The cell walls of the seventh leaf were significantly thicker than the first and second leaves at both 0.5 and $2 \mathrm{~cm}$ from the leaf tip at each sampling date, with the exception of the first leaf at 13 days (after treatment), $2 \mathrm{~cm}$ of the leaf tip, where the cell walls did not significantly differ from the seventh leaf.

\section{DISCUSSION}

Recent studies have suggested that ProCa triggers the production of flavanoids, not normally found in rosaceous species, that provide antimicrobial activity against E. amylovora, and that it is this activity that is the primary mechanism of fire blight control by $\mathrm{ProCa}(8,29)$. Since luteoforol can be neither measured nor extracted from apple tissue due to its high reactivity (8), the results of this study provide strong support against this hypothesis. Although disease incidence and severity were lowest in the ProCa-treated shoots compared with paclobutrazol- and nontreated shoots, significant reductions in incidence and severity were also found with the paclobutrazol treatment. It is highly unlikely that these reductions are due to luteoforol, because the paclobutrazol treatment is not known to trigger luteoforol production in apple shoots. It is possible that the ProCa treatment induces luteoforol production and the paclobutrazol treatment induces other novel flavanoids that result in disease control. However, this seems unlikely because E. amylovora populations were similarly high in ProCa-, paclobutrazol-, and nontreated tissue. Thus, even though luteoforol cannot be directly measured and we did not attempt to compare flavanoid content of ProCatreated apple shoots, our results suggest that ProCa treatment of apple shoots does not induce the production of chemicals with significant antimicrobial activity against $E$. amylovora.

Although studies detailing reductions in disease incidence and severity after application with ProCa $(7,19,20,21,34)$ are numerous, these studies did not examine E. amylovora population size following inoculation. Moreover, studies examining the phytoalexin-like properties of luteoforol $(8,29)$ did not assess effects on population size in planta. Examinations of populations of E. amylovora pathogenicity mutants in immature pear assays have shown that the mutant strains do not grow following inoculation (35). However, assessments of E. amylovora pathogenicity or virulence mutants following inoculations into apple shoots have typically focused on the percentage of blighted shoot, similar to our data presented in Figure 1B, instead of on reduced population size in shoots. We have determined that populations of an amylovoran-deficient pathogenicity mutant of E. amylovora are rapidly reduced over $10^{6}$-fold compared with a wild-type strain following apple shoot inoculation (J. M. Koczan and G. W. Sundin, unpublished information). Thus, the observation of extensive growth following inoculation and the finding of similar large populations of E. amylovora in symptomless shoots treated with growth regulators and symptomatic nontreated tissue was surprising.

These findings led us to investigate the alternate possibility that ProCa treatment would induce anatomical changes in apple tissue that affected fire blight control. One such observed change was the thickening of the cell walls of the midvein in the treated tissue of the youngest unfolded leaves compared with nontreated tissue. It is possible that these thickened cell walls of the parenchyma serve as a physical barrier that E. amylovora must breach in order to enter the xylem from interveinal tissue. The systemic migration of E. amylovora in plants is dependent in part upon a functional type III secretion system (23), and we hypothesize that the pathogen is incapable of successful interaction with host cells that have thickened cell walls.

Interestingly, it was also found that the mature seventh unfolded leaves of the nontreated tissue tended to have thicker cell walls than the first and second leaves. Often, the youngest leaves are more susceptible to fire blight infection (4,30). In our preliminary studies, inoculations of the sixth leaf and beyond did not lead to shoot infections in mature apple tree cvs. Fuji and Gala (data not shown). Suleman and Steiner (30) found that sorbitol concentrations increased and solute potentials decreased with apple leaf age. They speculated that this helps maintain the turgidity of the host cells because the solute potential of $E$. amylovora in the intercellular spaces needs to be more negative than the surrounding cells of the host for plasmolysis to occur. The reduced susceptibility of older leaves may be due to increased cell wall thickness, increased solute potential, or other physiological changes as the leaf matures and shoot elongation ceases. The inhibition of gibberellin biosynthesis and shoot elongation by ProCa and paclobutrazol may trigger analogous physiological changes leading to similar reductions in susceptibility.

It is evident that migration of E. amylovora through leaf tissue, into the leaf midvein, and from leaves into stem tissue needs to be studied in more depth to determine whether cell wall changes impede movement. Our results demonstrated that when $E$. amylovora was (presumably) introduced directly into the xylem

TABLE 1. Effect of prohexadione-calcium (ProCa) and paclobutrazol on the width of cell walls of the midvein cortical parenchyma tissue of apple cv. Gala

\begin{tabular}{|c|c|c|c|c|c|c|}
\hline \multirow[b]{3}{*}{ Leaf, treatment ${ }^{\mathrm{y}}$} & \multicolumn{6}{|c|}{ Midvein cell wall widths $(\mu \mathrm{m})$ with standard error on sampling date (days after treatment $)^{\mathrm{z}}$} \\
\hline & \multicolumn{3}{|c|}{ Veinal section $0.5 \mathrm{~cm}$ from leaf tip } & \multicolumn{3}{|c|}{ Veinal section $2 \mathrm{~cm}$ from leaf tip } \\
\hline & 7 days & 13 days & 21 days & 7 days & 13 days & 21 days \\
\hline \multicolumn{7}{|l|}{ First } \\
\hline Nontreated & $0.90 \pm 0.10 \mathrm{c}$ & $1.17 \pm 0.11 \mathrm{c}$ & $1.29 \pm 0.12 b$ & $1.64 \pm 0.11 \mathrm{c}$ & $2.04 \pm 0.16 \mathrm{c}$ & $1.65 \pm 0.09 \mathrm{c}$ \\
\hline ProCa & $1.67 \pm 0.07 \mathrm{a}$ & $2.36 \pm 0.07 \mathrm{a}$ & $1.81 \pm 0.11 \mathrm{a}$ & $2.26 \pm 0.30 b$ & $2.97 \pm 0.18 \mathrm{a}$ & $2.35 \pm 0.09 a$ \\
\hline Paclobutrazol & $1.18 \pm 0.10 b$ & $1.90 \pm 0.18 b$ & $1.70 \pm 0.19 \mathrm{a}$ & $2.57 \pm 0.17 \mathrm{a}$ & $2.45 \pm 0.15 b$ & $2.19 \pm 0.18 b$ \\
\hline \multicolumn{7}{|l|}{ Second } \\
\hline Nontreated & $0.97 \pm 0.02 \mathrm{c}$ & $1.82 \pm 0.12 \mathrm{c}$ & $1.35 \pm 0.19 \mathrm{c}$ & $1.65 \pm 0.13 \mathrm{c}$ & $1.92 \pm 0.03 \mathrm{c}$ & $1.75 \pm 0.13 \mathrm{c}$ \\
\hline ProCa & $1.85 \pm 0.05 \mathrm{a}$ & $2.56 \pm 0.08 b$ & $2.22 \pm 0.25 b$ & $1.91 \pm 0.06 b$ & $2.90 \pm 0.06 \mathrm{a}$ & $3.13 \pm 0.13 \mathrm{a}$ \\
\hline Paclobutrazol & $1.53 \pm 0.13 b$ & $2.75 \pm 0.19 \mathrm{a}$ & $2.54 \pm 0.13 \mathrm{a}$ & $2.07 \pm 0.15 \mathrm{a}$ & $2.68 \pm 0.06 b$ & $2.79 \pm 0.20 b$ \\
\hline \multicolumn{7}{|l|}{ Seventh } \\
\hline Nontreated & $1.89 \pm 0.03 \mathrm{a}$ & $2.04 \pm 0.01 \mathrm{c}$ & $2.32 \pm 0.04 \mathrm{a}$ & $2.51 \pm 0.05 \mathrm{a}$ & $2.22 \pm 0.02 b$ & $2.46 \pm 0.05 b$ \\
\hline ProCa & $1.92 \pm 0.08 \mathrm{a}$ & $2.49 \pm 0.19 \mathrm{a}$ & $2.37 \pm 0.20 \mathrm{a}$ & $2.59 \pm 0.06 \mathrm{a}$ & $2.82 \pm 0.05 \mathrm{a}$ & $2.94 \pm 0.06 \mathrm{a}$ \\
\hline Paclobutrazol & $1.94 \pm 0.11 \mathrm{a}$ & $2.34 \pm 0.17 b$ & $2.44 \pm 0.09 a$ & $2.52 \pm 0.04 \mathrm{a}$ & $2.86 \pm 0.11 \mathrm{a}$ & $2.93 \pm 0.14 \mathrm{a}$ \\
\hline
\end{tabular}

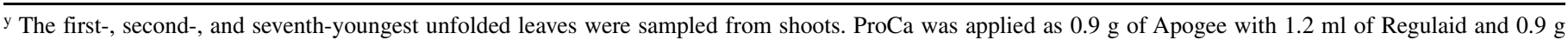
of ammonium sulfate per $946.1 \mathrm{ml}$ of water. Paclobutrazol was applied (basal drench) as $86.0 \mathrm{ml}$ of Cambistat with $1.2 \mathrm{ml}$ of Regulaid and $1.0 \mathrm{~g}$ of ammonium sulfate per $946.1 \mathrm{ml}$ of water.

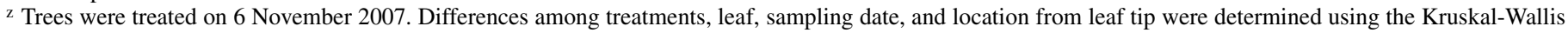
test followed by the post-hoc Games-Howell multiple comparison test when $P \leq 0.05$. Different letters (for each treatment, leaf, sampling date, and location) indicate significant differences $(P \leq 0.05)$. 
by the scissor-cut method, disease incidence was reduced in ProCa-treated compared with nontreated tissue. However, if lesions developed, they continued to expand along the shoot regardless of treatment with ProCa or paclobutrazol. This could be explained if ProCa or paclobutrazol treatment did not lead to a uniform thickening of cell walls in all cases, which would allow sporadic pathogenesis and further casts doubt on the possible induction of antimicrobial substances by ProCa. In order to determine the mechanism of control, a comprehensive study to determine the role that migration (both to the xylem and through the xylem) plays in fire blight disease development is required.

In summary, our results have led us to hypothesize that ProCa treatment leads to a decrease in apple shoot infection by E. amylovora through an alteration in tree physiology resulting in thickened cell walls in the cortical parenchyma, creating a physical barrier capable of stopping infection and systemic spread of the pathogen. ProCa has become an important tool for fire blight control, especially for apple growers dealing with $E$. amylovora strains that are resistant to streptomycin and in regions where trauma conditions are prevalent. If we are able to understand the mechanism of control by ProCa, it could aid in the development of additional materials for fire blight control.

\section{ACKNOWLEDGMENTS}

This work was supported by the Michigan Apple Committee, Michigan State University Project GREEEN, and the Agricultural Experiment Stations of Michigan and Kansas. This is contribution 09-082-J of the Kansas Agricultural Experiment Station. We thank G. Ehret for technical assistance.

\section{LITERATURE CITED}

1. Brooks, A. N. 1926. Studies of the epidemiology and control of fire blight of apple. Phytopathology 16:665-696.

2. Chiou, C. S., and Jones, A. L. 1993. Nucleotide sequence analysis of a transposon (Tn5393) carrying streptomycin resistance genes in Erwinia amylovora and other gram-negative bacteria. J. Bacteriol. 175:732-740.

3. Costa, G., Andreotti, C., Bucchi, F., Sabatini, E., Bazzi, C., Malaguti, S., and Rademacher, W. 2001. Prohexadione-ca (Apogee): Growth regulation and reduced fire blight incidence in pear. HortScience 36:931-933.

4. Crosse, J. E., Goodman, R. N., and Shaffer, W. H., Jr. 1972. Leaf damage as a predisposing factor in the infection of apple shoots by Erwinia amylovora Phytopathology 62:176-182.

5. Dickison, W. C. 2000. Integrative Plant Anatomy. Academic Press, San Diego, CA.

6. Evans, J. R., Evans, R. R., Regusi, C. L., and Rademacher, W. 1999. Mode of action, metabolism, and uptake of BAS 125w, Prohexadionecalcium. HortScience 34:1200-1201.

7. Fernando, W. G. D., and Jones, A. L. 1999. Prohexadione calcium-a tool for reducing secondary fire blight infection. Acta Hortic. 590:299-307.

8. Halbwirth, H., Kampan, W., Stich, K., Fischer, T. C., Meisel, B., Forkmann, G., and Rademacher, W. 2002. Biochemical and molecular biological investigations with respect to induction of fire blight resistance in apple and pear by transiently altering the flavonoid metabolism with specific enzyme inhibitors. Acta Hortic. 590:485-492.

9. Halbwirth, H., Martens, S., Wienand, U., Forkmann, G., and Stich, K. 2003. Biochemical formation of anthocyanins in silk tissue of Zea mays. Plant Sci. 164:489-495.

10. Hattingh, M. J., Beer, S. V., and Lawson, E. W. 1986. Scanning electron microscopy of apple blossoms colonized by Erwinia amylovora and $E$. herbicola. Phytopathology 76:900-904.

11. Jones, A. L. 2001. Challenges of controlling fire blight. Compact Fruit Tree 34:86-91.

12. Kishorekumar, A., Abdul Jaleel, C., Manivannan, P., Sankar, B., Sridharan, R., Somasundaram, R., and Panneerselvam, R. 2006. Differential effects of hexaconazole of Chinese potato (Solenostemon rotundifolius Poir., J. K. Morton). Acta Biol. Szegediensis 50:127-129.

13. Li, T. H., and Li, S. H. 2005. Leaf responses of micropropagated apple plants to water stress: nonstructural carbohydrate composition and regulatory role of metabolic enzymes. Tree Physiol. 25:495-504.

14. Loper, J. E., Henkels, M. D., Roberts, R. G., Grove, G. G., Willett, M. J., and Smith, T. J. 1991. Evaluation of streptomycin, oxytetracycline, and copper resistance in Erwinia amylovora isolated from pear orchards in Washington State. Plant Dis. 75:287-290.

15. Maxson-Stein, K., McGhee, G. C., Smith, J. J., Jones, A. L., and Sundin, G. W. 2003. Genetic analysis of a pathogenic Erwinia sp. isolated from pear in Japan. Phytopathology 93:1393-1399.

16. McManus, P. S., and Jones, A. L. 1994. Epidemiology and genetic analysis of streptomycin-resistant Erwinia amylovora from Michigan and evaluation of oxytetracycline for control. Phytopathology 84:627-633.

17. McManus, P. S., and Jones, A. L. 1994. Role of wind-driven rain, aerosols, and contaminated budwood in incidence and spatial pattern of fire blight in an apple nursery. Plant Dis. 78:1059-1066.

18. McManus, P. S., Stockwell, V. O., Sundin, G. W., and Jones, A. L. 2002. Antibiotic use in agriculture. Annual Review of Phytopathology 40:443465.

19. Momol, M. T., Ugine, J. D., Norelli, J. L., and Aldwinckle, H. S. 1999. The effect of prohexadione calcium, SAR inducers and calcium on the control of shoot blight caused by Erwinia amylovora on apple. Acta Hortic. 489:601-605.

20. Norelli, J. L., Jones, A. L., and Aldwinckle, H. S. 2003. Fire blight management in the twenty-first century: using new technologies that enhance host resistance in apple. Plant Dis. 87:756-765.

21. Norelli, J. L., and Miller, S. S. 2004. Effect of prohexadione-calcium dose level on shoot growth and fire blight in young apple trees. Plant Dis. 88:1099-1106.

22. Ockey, S. C., and Thomson, S. V. 2006. Preventing shoot blight of apple with streptomycin applications following simulated hail injury. Acta Hortic. 704:211-216.

23. Oh, C. S., and Beer, S. V. 2005. Molecular genetics of Erwinia amylovora involved in the development of fire blight. FEMS Microbiol. Lett. 253:185-192.

24. Petracek, P. D., Silverman, F. P., and Greene, D. W. 2003. A history of commercial plant growth regulators in apple production. HortScience 38:937-942.

25. Psallidas, P. G., and Tsiantos, J. 2000. Chemical control of fire blight. Pages 199-234 in: Fire Blight: The Disease and Its Causative Agent, Erwinia amylovora. J. L. Vanneste, ed. CABI Publishing, Wallingford, Oxon, UK.

26. Rademacher, W. 2000. Growth retardants: Effects on gibberellin biosynthesis and other metabolic pathways. Annu. Rev. Plant Physiol. Plant Mol. Biol. 51:501-531.

27. Römmelt, S., Treutter, D., Speakman, J. B., and Rademacher, W. 1999. Effects of prohexadione-Ca on the flavonoid metabolism of apple with respect to plant resistance against fire blight. Acta Hortic. 489:359-363.

28. Sopher, R. C., Krol, M., Huner, N. P. A., and Fletcher, R. A. 1999. Chloroplastic changes associated with paclobutrazol induced stress protection in maize seedling. Can. J. Bot. 77:1-12.

29. Spinelli, F., Speakman, J., Rademacher, W., Halbwirth, H., Stich, K., and Costa, G. 2005. Luteoforol, a flavan 4-ol, is induced in pome fruits by prohexadione-calcium and shows phytoalexin-like properties against Erwinia amylovora and other plant pathogens. Eur. J. Plant Pathol. 112:133-142.

30. Suleman, P., and Steiner, P. W. 1994. Relationship between sorbitol and solute potential in apple shoots relative to fire blight symptom development after infection by Erwinia amylovora. Phytopathology 84:1244-1250.

31. Sundin, G. W., Werner, N. A., Yoder, K. S., and Aldwinckle, H. S. 2009. Field evaluation of biological control of fire blight in the eastern United States. Plant Dis. 93:386-394.

32. Thomson, S. V. 1986. The role of the stigma in fire blight infections. Phytopathology 76:476-482.

33. van der Zwet, T., and Keil, H. L. 1972. Importance of pear-tissue injury to infection by Erwinia amylovora and control with streptomycin. Can. J. Microbiol. 18:893-900.

34. Yoder, K. S., Miller, S. S., and Byers. R. E. 1999. Suppression of fire blight in apple shoots by prohexadione-calcium following experimental and natural inoculation. HortScience 34:1202-1204.

35. Zhao, Y., Blumer, S. E., and Sundin, G. W. 2005. Identification of Erwinia amylovora genes induced during infection of immature pear tissue. J. Bacteriol. 187:8088-8103.

36. Zhou, W. J., Shen, H. C., Xi, H. F., and Ye, Q. F. 1993. Studies on the regulation mechanism of paclobutrazol to the growth of rape plant. Acta Agric. Zhejiang 19:316-320. 